\title{
Financial Analysis of Basmati Rice Production in Jammu Region of J\&K, India
}

\section{Shaurya Sharma*, Sudhakar Dwivedi, Pawan Kumar Sharma, Sunish Sharma, Vinod Gupta and A.K. Singh}

Sher-e-Kashmir University of Agricultural Sciences and Technology of Kashmir, Jammu, JEK, India

*Corresponding author: shauryasharma396@gmail.com

Received: $19-07-2020$

Revised: 24-11-2020

Accepted: $29-11-2020$

\section{ABSTRACT}

The present study was conducted in Jammu district of J\&K. Two blocks of Basmati rice producing were selected purposively. Further, two villages from each selected block were selected randomly and from each village twenty five basmati growers were studied randomly through personal interview method, comprising a total of 100 Basmati rice grower. The study revealed that medium farms were having highest percentage share (40.49 per cent) followed by marginal (34.11 per cent) and small (25.40 per cent). The per hectare total input cost on overall farms comes to ₹ 27529.27. The highest cost of input per hectare was observed on Marginal farm (₹ 27959.00) followed by small farm (₹ 27414.00) and medium farm (₹ 27297.00). The highest total cost was observed in marginal farm (₹ 29561.00) followed by small (₹ 29019.00) and medium (₹ 28889.00). The per quintal gross returns on overall comes to ₹ 4191.08. The maximum gross return was observed in medium farms ( $₹ 4417.97)$ followed by small (₹ 4167.59) and marginal farm (₹ 3964.43). The overall net returns came ought to be ₹ 82, 14,141.85 out of which the maximum net return was observed in medium farm (₹ 33,58,416.50) followed by marginal farm (₹ 28,12,339.39) and small farm (₹ 20,09,143.07).

Keywords: Basmati rice, Gross returns, Concentration, Net return, Input.

Rice (Oryza sativa) is very important cereal crop in the world. For over 6500 years ago its cultivation has started in many countries. Rice acquires an area of 161 million hectares and 678 million tonnes of annual production all over the world. Among all countries China is a leading rice producing country followed by India and Indonesia (FAOs, 2015). In India rice acquire an area of 43.86 million hectare and production of about 104.32 million tonnes (Department of co-operation and farmer's welfare 2015-2016). Rice is classified under two categories -Basmati and non basmati. Basmati is a variety of long slender-grained aromatic rice which is traditionally from the Indian subcontinent. Basmati is also known as 'Queen of Rice', has originated from Vasumati which means 'earth recognized by its fragrance' (Nene 2005). It has a different combination of varieties that has positioned the grain to achieve higher pricing in the marketplace. As of 2018-2019, India exported to over $90 \%$ of the overseas Basmati rice market. India is a leading exporter of Basmati rice to the global market. India has been the world's top rice exporter since the beginning of this decade and the world's largest rice exporter in 2011-2012 displacing Thailand from its leadership position.

\footnotetext{
How to cite this article: Sharma, S., Dwivedi, S., Sharma, P.K., Sharma, S., Gupta, V. and Singh, A.K. (2020). Financial Analysis of Basmati Rice Production in Jammu Region of J\&K, India. Agro Economist - An International Journal, 7(2): 95-99.

Source of Support: None; Conflict of Interest: None
} 
Export of Basmati rice stood at 2.3 and 3.2 million tonnes in these two years. India shares a world's export in recent years (2014-2018) has stayed at 25$26 \%$. As a result, the exports to production ratio for rice in India arose from $2.4 \%$ in $2009-2010$ to $6.8 \%$ in 2011-2012 and 9.6\% in 2012-2013, after which it has fluctuated between 9.9 to $11.3 \%$. In export two factors played a great role. The first was the government decision in February 2011 to uplift a four year ban on exports of non-basmati varieties of rice and second decision of Thai government under Prime minister Yingluck Shinawatra, which was taken in same year in favour of farmers by strengthening a Rice Pledging Scheme under which they promised to procure unlimited stocks at an enhanced price that reflected a 50\% increase over 2010. This shows the significant price difference between Basmati and non-basmati rice varieties. Jammu and Kashmir produces about 1 lakh metric tonnes of varieties of Basmati rice. Basmati of Jammu region particularly in R.S Pura belt is world famous for its aroma (Kumar et al.). Basmati can be grown where precise climatic condition, soil quality and temperature exist. It is believed that there will be a sustained growth of Basmati rice in coming years due to the development of 'PUSA 1121 Basmati' and it has significant advantages over traditional variety of Basmati (Vaid et al. 2017). There have been various varieties of Basmati notified under the seed act, 1966. Basmati crop is generally a kharif crop where sowing season starting from May-June and harvesting season ending in October-November. Rice in Jammu \& Kashmir is grown only once in a year because of extreme climatic condition. Transplanting of rice in J\&K is done manually or by broadcasting method. In Jammu and Kashmir people use two methods for grow rice, especially in Jammu they prepare their fields by Tao \& Kenlu method.

\section{MATERIALS AND METHODS}

The present study is an attempt to identify the market dynamics of Basmati rice in Jammu district of J\&K. The study was based on primary and secondary data. The primary data for the agricultural year (2018-2019) were collected from study area. Two blocks based on highest area under Basmati crop were selected from Jammu district purposively. Further, two villages from each selected block were selected randomly. A list of Basmati rice grower from each village was prepared separately. Twenty five Basmati farming household were selected randomly from each village. Thus, a total of 100 Basmati rice growers were selected from the study area.

\section{RESULTS AND DISCUSSION}

The cost structure as reflected by share of various inputs in total variable cost is determined by the level of technology and use of modern inputs. Variation in use of various inputs on different size groups of farms show the difference in level of technology adopted on the respective farm. The knowledge of cost and return structure is important for assessing the need for steps to fill the gap to raise the overall economic viability of farming. Thus, it is very important to evaluate the economics of crop enterprise on respective farm groups in the study area. A status of basmati area on different category of farms revealed that total area under basmati and non-basmati rice cultivation on sample farms was 70.71 hectares (Table 1 and 2 ) which constituted 86.04 per cent of the gross crop area and on average per farm area under basmati were 70.71 ha.

Category wise highest area (93.83 per cent) of basmati rice was under large holdings followed by 83.57 per cent on small farms and 80.42 per cent on marginal farms respectively. Thus, as the farm size increases, the percentage area of basmati rice also increases.

The total area under non-basmati cultivation on sample farms was 11.28 hectares which includes 5.87 hectares of marginal, 3.53 hectares of small and 1.88 hectares of medium size farms.

The various components of per hectare cost of cultivation are presented in Table 3 . The overall total variable cost of sample farms including cost involving the post-harvest operations was ₹ 29127.98 per hectare. Out of this variable input cost accounted for about 94.51 per cent whereas the rest amount 5.49 per cent constituted the post harvest/marketing cost. Category wise, the lowest cost i.e. ₹ 28889.00 per hectare was observed on medium farms and the highest i.e. ₹ 29561.00 per hectare on the marginal category farms. It reveals that farm size increases the cost of basmati production and marketing decreases. Proportionate share of variable input cost in total cost on all the category farms was more or less about the same at 94.47 to 94.58 per cent on all the groups of farms, the major share of total variable input cost was 
Table 1: Area under different variety of rice (ha)

\begin{tabular}{|c|c|c|c|c|c|}
\hline \multirow{2}{*}{ Farm category } & \multicolumn{3}{|c|}{ Basmati } & \multirow{2}{*}{$\begin{array}{l}\text { Non-Basmati } \\
\text { Coarse }\end{array}$} & \multirow{2}{*}{ Total } \\
\hline & Local & Pusa 1121 & Total & & \\
\hline Marginal & 19.77 (65.92) & 4.35 (14.50) & $24.12(80.42)$ & 5.87 (19.57) & 29.99 (100.00) \\
\hline Small & 13.56 (63.10) & 4.40 (20.47) & 17.96 (83.57) & 3.53 (16.43) & $21.49(100.00)$ \\
\hline Medium & $19.02(62.34)$ & 9.61 (31.49) & $28.63(93.83)$ & $1.88(6.17)$ & $30.51(100.00)$ \\
\hline Total & 52.35 (63.85) & 18.36 (22.39) & 70.71 (86.04) & $11.28(13.76)$ & $81.99(100.00)$ \\
\hline
\end{tabular}

Table 2: Concentration of area under basmati

\begin{tabular}{lll}
\hline Farm Category & Total area under basmati crop (in ha) & \% share to total \\
\hline Marginal & $24.12(0.36)$ & 34.11 \\
Small & $17.96(0.94)$ & 25.40 \\
Medium & $28.63(2.04)$ & 40.49 \\
Total & $70.71(0.71)$ & 100.00 \\
\hline
\end{tabular}

Table 3: Cost of basmati production and marketing (₹/ha)

\begin{tabular}{|c|c|c|c|c|}
\hline \multirow{2}{*}{ Particulars } & \multicolumn{4}{|c|}{ Farm Category } \\
\hline & Marginal & Small & Medium & Overall \\
\hline \multicolumn{5}{|l|}{ I) Input Costs(₹/ha) } \\
\hline Seed & 1317.00 & 1330.00 & 1357.00 & 1336.50 \\
\hline Irrigation & 1650.00 & 1386.50 & 1350.00 & 1415.40 \\
\hline Manure and fertilizer & 2921.00 & 2987.50 & 3023.00 & 2979.19 \\
\hline Labour (bullock + human) & 14250.00 & 14387.00 & 14520.0 & 13395.09 \\
\hline Machinery hire charges & 5951.00 & 5427.00 & 5326.0 & 5398.21 \\
\hline Pesticides/weedicides & 1870.00 & 1896.00 & 1721.00 & 1814.67 \\
\hline I) Total input cost & 27959.00 & 27414.00 & 27297.00 & 27529.27 \\
\hline \multicolumn{5}{|c|}{ II) Storage, Transportation and Marketing Cost (₹/ha) } \\
\hline Storage & 0.00 & 20.00 & 32.00 & 18.04 \\
\hline Transportation cost & 810.00 & 750.00 & 730.00 & 762.37 \\
\hline Marketing losses & 150.00 & 160.00 & 135.00 & 146.47 \\
\hline Marketing (unloading, cleaning etc.) & 602.00 & 590.00 & 576.00 & 588.42 \\
\hline Kind payment & 0.00 & 80.0 & 110.00 & 64.86 \\
\hline Misc. & 0.00 & 5.00 & 9.00 & 3.85 \\
\hline $\begin{array}{l}\text { II) Total storage, transportation and marketing } \\
\text { cost }\end{array}$ & 1602.00 & 1605.00 & 1592.0 & 1598.71 \\
\hline \multicolumn{5}{|l|}{ Per cent share to the total cost (I+II) } \\
\hline Total input $\operatorname{cost}(\mathrm{I})$ & 94.58 & 94.47 & 94.49 & 94.51 \\
\hline $\begin{array}{l}\text { Total storage, transportation and marketing cost } \\
\text { (II) }\end{array}$ & 5.42 & 5.53 & 5.51 & 5.49 \\
\hline $\operatorname{Productivity(q/ha)}$ & 29.72 & 27.23 & 26.78 & 27.90 \\
\hline Total cost (I+II) & 29561.00 & 29019.00 & 28889.00 & 29127.98 \\
\hline
\end{tabular}


contributed by labour cost to the tune of ₹ 14250.00 on marginal farms followed by ₹ 14387.00 on small farms and ₹ 14520.00 on medium farms respectively. Overall machinery cost comes to $₹ 5398.21$ per hectare followed by ₹ 5326.00 on medium farms, ₹ 5427.00 on small farms and $₹ 5951.00$ on marginal farms respectively. Similarly in case of pesticide/ weedicide cost it was comes to ₹ 1814.67 per hectare on overall farms followed by ₹ 1721.00 on medium farms, ₹ 1870.00 on marginal farms and ₹ 1896.00 on small farms. The intensity of labour use increases to decrease the farm size category (Table 3). The cost of manure and fertilizer on overall farms comes to ₹ 2979.19 per hectare whereas it was highest on medium farms i.e. ₹ 3023.00 followed by ₹ 2987.50 on small farms and ₹ 2921.00 on marginal farms respectively.

It is imperative for all the farmers to judicious use of resources at their command to derive maximum possible per hectare economic benefits, thereby rise in the living standard of farm household (Table 4). The average price received by overall farms was turned out to ₹ 4032.02 per quintal. The gross return on overall farms were ₹ 8243269.83 in which it was ₹ 2841900.39 on marginal farms, ₹ 2038162.07 on small farms and ₹ 3387305.50 on medium farms respectively. It is worth mentioning that in gross returns the value of by product also added in all categories of farms. There was 70.71 hectare area under basmati cultivation on total farms in which it was 24.12 hectares on marginal farms, 17.96 hectares on small farms and 28.63 hectares on medium farms respectively. The total production was 1972.61 quintals which includes $716.85 \mathrm{q}$ on marginal farms, 489.05 on small and $766.71 q$ on medium farms. There is a significant variation in price received on sale of basmati rice in all different type of farms. It was lowest on marginal farms i.e. ₹ 3830.00 , followed by $₹ 4020.00$ on small farms and ₹ 4260.00 on medium farms. This is due to the trend of per quintal price received by the farmers due to their time of sale of

Table 4: Return from basmati production

\begin{tabular}{lllll}
\hline \multirow{2}{*}{ Particulars } & \multicolumn{3}{c}{ Farm Category } \\
\cline { 2 - 5 } & Marginal & Small & Medium & Overall \\
\hline Area (ha) & 24.12 & 17.96 & 28.63 & 70.71 \\
Production (q) & 716.85 & 489.05 & 766.71 & 1972.61 \\
Price received on sale (₹/q) & 3830.00 & 4020.00 & 4260.00 & 4032.02 \\
Returns (₹) & & & & \\
Main Product & 2745535.50 & 1965981.00 & 3266184.60 & 7953602.97 \\
By-product & 96364.89 & 72181.07 & 121120.90 & 289666.86 \\
Gross Returns & 2841900.39 & 2038162.07 & 3387305.50 & 8243269.83 \\
Cost (₹) & & & & \\
Input cost & 674371.08 & 490710.60 & 781513.11 & 1946594.79 \\
Marketing cost & 38640.24 & 28825.80 & 45578.96 & 113045.00 \\
Total variable costs & 713011.32 & 519535.40 & 821092.07 & 2053638.79 \\
ROVC & 2128889.07 & 1518626.67 & 2566213.43 & 6189631.04 \\
Total variable cost (₹/ha) & 29561.00 & 28927.36 & 28679.43 & 29043.12 \\
Gross returns (₹/ha) & 117823.40 & 113483.41 & 118313.15 & 116578.56 \\
ROVC (₹/ha) & 88262.40 & 84556.05 & 89633.72 & 87535.44 \\
Total variable cost (₹/q) & 994.65 & 1062.34 & 1070.93 & 1041.08 \\
Gross returns (₹/q) & 3964.43 & 4167.59 & 4417.97 & 4191.08 \\
ROVC (₹/q) & 2969.78 & 3105.26 & 3347.05 & 3137.79 \\
Quantity sold (q) & 680.05 & 442.13 & 625.94 & 1748.12 \\
Value of marketed surplus & 2604591.50 & 1777362.60 & 2666504.40 & 7048454.80 \\
\hline
\end{tabular}


produce. The total net returns comes to ₹ 8214141.85 in which it was ₹ 2812339.39 on marginal farms, ₹ 2009143.06 on small farms and ₹ 3358416.50 on medium farms respectively. The total marketing cost was ₹ 113045.00 , while it was ₹ 38640.24 on marginal farms, ₹ 288250.80 on small farms and ₹ 45578.96 on medium farms. The return over variable cost on all farms was ₹ 6189631.04 in which it was ₹ 212889.07 on marginal farms, ₹ 1518626.67 on small farms and ₹ 2566213.43 on medium farms. Per hectare return over variable cost was ₹ 87535.44 of overall farms, on marginal farms it was ₹ 88262.40, on small farms $₹ 84556.05$ and on medium farms $₹ 89633.72$ on medium farms. The total variable cost per quintal was ₹ 1041.08 on overall farms. However, it was ₹ 994.65 on marginal farms, ₹ 1062.34 on small farms and $₹ 1070.93$ on medium farms. The overall gross return per quintal was ₹ 4191.08 and varies from ₹ 3964.43 on marginal farms, 4167.59 on small farms and $₹ 4417.97$ on medium farms. The return over variable cost per quintal was ₹ 3137.79 on overall farms and varies from ₹ 2969.78 on marginal farms, $₹ 3105.26$ on small farms and ₹ 3347.05 on marginal farms. The total value of marketed surplus was ₹ 7048454.80. This involves ₹ 2604591.50 on marginal farms, ₹ 1777362.60 on small farms and ₹ 2666504.40 on medium farms.

\section{CONCLUSION}

On an average per farm area under basmati rice was 70.71 ha. The overall total variable cost of sample farms including cost involving the post-harvest operations was ₹ 29127.98 per hectare. Out of this, variable input cost accounted for about 94.51 per cent whereas 5.49 per cent constituted the post-harvest/ marketing cost. The overall machinery cost was ₹ 5398.21 per hectare. The overall gross return per quintal was $₹ 4191.08$ and the total value of marketed surplus was ₹ 7048454.80. The majority of farmers are marginal and small resulted in small surplus. This is the reason that they are unable to bargain for the better price of their produce. In such situations, Farmer Producer Organization (F.P.O) is needed for collective marketing of basmati rice. It is observed that the price of basmati rice goes high at the time of export when opened whereas price goes down when the export is banned. So, there is a need to adopt suitable export policy for basmati rice.

\section{REFERENCES}

Dwivedi, S.M.C. and Singh, T. 2011. An Economic Analysis of Basmati Rice Production in Jammu district of Jammu and Kashmir. Journal of Research, SKUAST-J, 10(1): 93-99.

Food and Agriculture Organization (FAO). 2015. Rice Market Monitor. Available online with updatesathttp:// www.fao.org/fileadmin/templates/est/COMM_ MARKETS_MONITORING/Rice/Images /RMM/ RMM_APR15.pdf

Kaloo, M.J. and Choure, T. 2015. Status of rice production in Jammu and Kashmir: An economic analysis. International Journal of Applied research, 2(1): 359-363.

Kumar, N., Tripathi, N.K. and Tomer, R.S. 2019. Marketing of basmati rice in Jammu district of JEK state: an economic analysis of marketing channels and their efficiency, 1(2): 19-21.

Nene, Y.L. 2005. Rice Research in South Asia through Ages1. Asian Agricultural History, 9(2): 85-106.

Nuzhat, I. 1993. Economic Analysis of the Effects of Rice Price Distortions in Pakistan: 1975-90. The Pakistan Development Review, 32(4): 859-872.

Vaid, A., Sharma, P.K., Mahajan, V., Ajrawat, B., Jamwal, A. and Gupta, S. 2017. Economic Impact of Frontline Demonstrations on Basmati Rice. Agro-Economist, 4(2): 79-83. 
